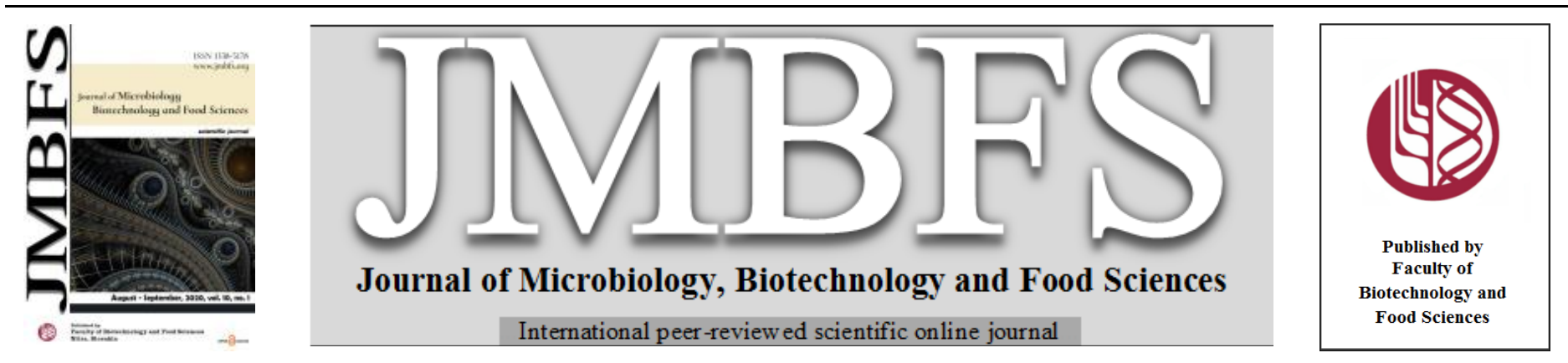

\title{
THE POTENTIAL OF BUTON FOREST ONION Eleutherine bulbosa (Mill.) Urb. EXTRACT AS A PREBIOTIC AND AN ANTIOXIDANT
}

\author{
Waode Munaeni ${ }^{1,2}$, Widanarni Widanarni ${ }^{1}$, Munti Yuhana* ${ }^{1}$, Mia Setiawati $^{1}$, Aris Tri Wahyudi ${ }^{3}$ \\ Address(es): \\ ${ }^{1}$ Department of Aquaculture, Faculty of Fisheries and Marine Science, IPB University (Bogor Agricultural University), Bogor 16680, Indonesia. \\ ${ }^{2}$ Department of Aquaculture, Faculty of Fisheries and Marine Science, Halu Oleo University, Kendari 93232, Indonesia. \\ ${ }^{3}$ Department of Biology, Faculty of Mathematics and Natural Science, IPB University (Bogor Agricultural University), Bogor 16680, Indonesia.
}

*Corresponding author: yuhanamunti@gmail.com

doi: 10.15414/jmbfs.2020.10.1.107-111

\section{ARTICLE INFO}

Received 18. 5. 2019

Revised 24. 3. 2020

Accepted 31. 3. 2020

Published 1. 8. 2020

Regular article open $\partial_{\text {ACCESS }}$

\begin{abstract}
The aim of this study was to analyze the potential of Buton forest onion extract (BFOE) Eleutherine bulbosa (Mill.) Urb. as a prebiotic and an antioxidant. Buton forest onion was extracted using $96 \%$ ethanol by maceration method. The prebiotic content of BFOE was determined using high performance liquid chromatography (HPLC). The ability of BFOE as a prebiotic was analyzed the growth of Pseudoalteromonas piscicida $1 \mathrm{Ub}$ and Bacillus sp. NP5.and its resistance to artificial gastric acid and $\alpha$-amylase. Antioxidant activities were determined using 2,2-diphenyl-1-picrylhidrazyl (DPPH). Results indicate that the content of the oligosaccharides of BFOE including inulins, fructooligosaccharides (FOS), galactooligosaccharides (GOS), and raffinoses was 2.1\%, 10\%, $1 \%$ and $7.5 \%$, respectively. The mixed oligosaccharides were found capable to stimulate the growth of $P$. piscicida $1 \mathrm{Ub}$ and Bacillus sp. NP5. The optimum BFOE concentration to stimulate the growth of probiotics was $1.25 \mathrm{mg} / \mathrm{mL}(0.17 \pm 0.02$ and $0.21 \pm 0.00)$. The mixed oligosaccharides were also resistant to hydrolysis of artificial gastrice acid and $\alpha$-amylase, with maximum hydrolysis percentages of $8.25 \pm 0.25 \%$ and $27.52 \pm 1.68 \%$, respectively. The BFOE was capable to DPPH radical scavenge with IC50 of $1.48 \mu \mathrm{g} / \mathrm{mL}$. The BFOE of this study has the potential to be a prebiotic and an antioxidant.
\end{abstract}

\section{INTRODUCTION}

Buton forest onion Eleutherine bulbosa (Mill.) Urb. of the family Iridaceae, has green leaves, white flowers and red bulbs that resemble the shape of red onion bulbs. Buton forest onions are known various names in Indonesia, such as bawang sabrang, bawang dayak, babawangan beureum, bawang hantu, bawang siyem, bawang kapal, bawang sayup, and bawang lubak (Febrinda, 2014). E bulbosa (Mill.) Urb. is also known by such names as E. americana, E. anomala Herb., E. longifolia Gagnep., Bermudiana bulbosa (Mill) Molina, Cipura plicata (Sw.) Griseb., E. plicata (Sw.) Herb., Ferraria parviflora Salisb., B. congesta (Klatt) Kuntze, Galatea americana (Aubl.) Kuntze, G. bulbosa (Mill.) Britton, G. plicata (Sw.) Baker, Ixia americana Aubl, E. Subaphylla Gagnep, Sisyrinchium americanum (Aubl) Lemee, S. bulbosum Mill., S. capitatum Pers., S. congestum Klatt, S. elatum, S.latifolium Sw., S. plicatum, and S. racemosum Pers. (http://www.theplantlist.org/tpl/record/kew-327974).

$E$. bulbosa contain bioactive compounds of naphthalene, naphthoquinone, anthraquinone (Mahaburasakam et al., 2010; Ieyama et al., 2011), flavonoid, tannin, saponin, steroid, triterpenoid groups (Munaeni et al., 2017), securixantone (Munaeni et al., 2019a). The E. bulbosa are anti-microbial, antiinflammatory, anti-hypertensive, anti-diabetic, and capable of being virus replication inhibitors (Insanu et al., 2014). Buton forest onion extract (BFOE) is capable to inhibit Staphylococcus aureus (Ifesan et al., 2009; Subramaniam et al., 2012), and Vibrio harveyi (Munaeni et al., 2017), and potential to increase the growth performance of vannamei shrimp (Litopenaeus vannamei) (Munaeni et al., 2019b).. The E. bulbosa is able to reduce the occurrence of lipid peroxidation in diabetic rat liver (Febrinda et al., 2014). In addition, according to Phoem \& Voravuthikunchai (2013), E. americana is potential as a prebiotic because it can increase the growth of intestinal microbiotas (Bacteroides population).

Prebiotics are foods that cannot be utilized by the host because the amylase or other hydrolases in the intestinal tract cannot be digested (Carabin et al., 1999) but they can be digested or fermented selectively by the microbiotas in the digestive tract that will benefit the host (Gibson et al., 2004). Some criteria of prebiotics include their being resistant to hydrolysis by artificial gastric acid, $\alpha$ - amylase, and bile salt being able to be fermented by intestinal microbes and being able to stimulate the growth of probiotics in the digestive tract (Wichienchot $\boldsymbol{e} t$ al., 2010; Sawangwan et al., 2018). Oligosaccharides are prebiotic sources that have been widely used in mammals and fish (Mahiuos et al., 2006). Prebiotic oligosaccharides include fructo-oligosaccharides (FOS), galacto-oligosaccharides (GOS), xylo-oligosaccharides (XOS), isomalto-oligosaccharides (IMO), raffinoses, lactosucroses, soy-oligosaccharide (SOS), palatinoses, inulins, oligofructoses (OF), isomaltuloses, arabinoxyoligosaccharides, soligosaccharides, galactosil lactose, and pyrodextrinsares (Mohanti et al., 2018). Antioxidants are substances that can significantly prevent oxidation on the substrate at a low concentration (Halliwell, 1990). Antioxidants are able to stabilize free radicals by donating of electrons, inhibiting the occurrence of chain reactions from the formation of free radicals; acting as free radical scavenger, and converting free radicals into compounds that are nonreactive and relatively stable by donating hydrogen atoms (Kim et al., 2014). Phytochemical compounds from plants are able to contribute as natural antioxidants, making it necessary to conduct a study to obtain an optimum antioxidant efficiency (Sahren $\boldsymbol{e t}$ al., 2010; Mihaylova $\boldsymbol{e t}$ al., 2019). However, no studies to observed the content of oigosaccharides in Buton forest onion E. bulbosa (Mill) Urb. extract and their role as prebiotics. Thus, the aim of this study was to analyze the potential of the oligosaccharides in Buton forest onion E. bulbosa (Mill) Urb. extract as a prebiotic and an antioxidant.

\section{MATERIAL AND METHODS}

\section{Collection and identification of plant material}

The bulbs of Buton forest onion were obtained from Kumbewaha Village, Buton Regency, South East Sulawesi, Indonesia, then identified at the Botany Division, Reseach Center for Biologi, Indonesian Institutite of Sciences (No. 1000/1PH.1.01/11.07/V/2018). 


\section{Processing of plant materials and extract preparation}

Extraction of Buton forest onion bulbs was carried out using the maceration method (Munaeni et al., 2017). Buton forest onion bulbs were cleaned and thinly sliced then dried in an oven at a temperature of $60{ }^{\circ} \mathrm{C}$ for 48 hours. The sample was powdered using a blender (Miyako, Japan), then extracted using $96 \%$ ethano at a ratio of 1:4 $(\mathrm{w} / \mathrm{v})$ for 24 hours at room temperature using a magnetic stirrer. The maceration yield was filtered using Whatman's filter paper No. 41, then the filtered leaving was re-macerated twice using the same method. The maceration yield was thickened using a vacuum evaporator at $40{ }^{\circ} \mathrm{C}$. The extract was then stored in a freezer at $-20{ }^{\circ} \mathrm{C}$ for further analysis.

\section{Microorganism preparation}

Stimulation test on the growth of probiotics was done using two types of bacteria namely probiotic and enteric bacteria. The probiotic bacteria used were P.piscicida 1Ub and Bacillus sp. NP5, while the enteric bacteria used Vibrio parahaemolyticus. $P$. piscicida $1 \mathrm{Ub}$, were probiotics isolated from vanname shrimp nauplii (Widanarni et al., 2009). Bacillus sp. NP5 were probiotics isolated from the digestive tract of tilapia (Putra et al., 2015). $V$ parahaemolyticus were collected from the Research Center of Brackishwater Aquaculture and Fisheries Counseling, Maros, South Sulawesi. All these bacteria were grown at $37{ }^{\circ} \mathrm{C}$ and reared at $4{ }^{\circ} \mathrm{C}$ on SWC agar slant (sea water complete: $\mathrm{g}$ of yeast extract, $3 \mathrm{~mL}$ of glycerol, $5 \mathrm{~g}$ of bactopeptone, $250 \mathrm{~mL}$ of distilled water, and $750 \mathrm{~mL}$ of seawater)

\section{Oligosaccharide Content of Buton Forest Onion Extract (BFOE)}

The type and concentration of oligosaccharides in BFOE were determined using high performance liquid chromatography (HPLC). The galactooligosaccharides (GOS) and raffinoses analyze was based on AOAC 2001.02 method, while the inulins and fructooligosaccharides (FOS) analyze was based on AOAC 997.08 method. Twenty $\mu \mathrm{L}$ of sample was injected in a gel TSK Amido- 8 column $(4.6 \times$ $250 \mathrm{~mm}$, Tosoh, Tokyo, Japan) and LC-10ADVP pumps (Shimadzu, Kyoto, Japan). A Refractive Index (RI) detector was used, and the column temperature was $35^{\circ} \mathrm{C}$. Mobile phase was acetonitrile and water (ratio 80:20) with a flow rate of $1 \mathrm{~mL} /$ minute. The sugar concentration in the sample was obtained by comparing the peak area of the standard curve.

\section{Activity of Buton Forest Onion Extract (BFOE) in Probiotic Growth Stimulation}

The activity of BFOE in the stimulation of probiotic growth was analyzed using the spectrophotometric methods, refers to Huebner et al., (2008) with minor modifications. The BFOE was diluted using sterile distilled water at concentrations at $10,5,2.5,1.25,0.625,0.313$, and $0.156 \mathrm{mg} / \mathrm{mL}(\mathrm{b} / \mathrm{v})$, each repeated triplicate. One $\mathrm{mL}$ of $\mathrm{BFOE}$ from each concentration was added into 10 $\mathrm{mL}$ of liquid SWC medium, while the control only used the medium. The bacterial suspension was culture in liquid SWC medium at $28-29{ }^{\circ} \mathrm{C}$ at $140 \mathrm{rpm}$ for $18 \mathrm{~h}$ for $P$. piscicida $1 \mathrm{Ub}$ and Bacillus sp. NP5 and $14 \mathrm{~h}$ for $V$. parahaemolyticus. The bacterial suspension (density of $10^{8} \mathrm{CFU} / \mathrm{mL}$ ) was inoculated into each treatment $(\mathrm{v} / \mathrm{v})$ by $5 \%$, then incubated at a temperature of $28-29^{\circ} \mathrm{C}$ at $140 \mathrm{rpm}$. The optical density (OD) of the supernatant was analyzed using a spectrophotometer UV-200-RS at a wavelength of $600 \mathrm{~nm}$, then the blanks used liquid SWC medium without bacteria. Observations of BFOE to the stimulation of probiotic growth were conducted for 14, 18, and $24 \mathrm{~h}$. The blanks used media without bacteria. Prebiotic activity scores were expressed quantitatively by the following formula (Huebner et al., 2008):

$$
\text { Prebiotic activity scores }=\frac{\log P p t-\log P p 0}{\log P g t-\log P g 0}-\frac{\log E p t-\log E p 0}{\log \text { Egt }-\log E g 0}
$$

where Ppt was probiotic log OD on the BFOE at $\mathrm{t}-\mathrm{h}$ ( $\mathrm{t}$, time; $\mathrm{h}$, hour), $\mathrm{Pp} 0$ was probiotic log OD on the BFOE at $0-\mathrm{h}, \mathrm{Pgt}$ was probiotic log OD on control/media at $\mathrm{t}-\mathrm{h}, \mathrm{Pg} 0$ was probiotic $\log \mathrm{OD}$ on control/media at $0-\mathrm{h}$, Ept was enteric log OD on the BFOE at t-h, Ep0 was enteric log OD on the BFOE at $0-\mathrm{h}$, Egt was enteric $\log \mathrm{OD}$ on control/media at $\mathrm{t}-\mathrm{h}$, and $\mathrm{Eg} 0$ was enteric $\log \mathrm{OD}$ on control/media at 0 -h.

High prebiotic activity scores indicate that the substrates of the oligosaccharide samples had increased the growth of probiotics while the enteric bacteria yielded lower growth.

\section{Resistance of Buton Forest Onion Extract (BFOE) to hydrolysis by artificia gastric acid}

Testing of the resistance of BFOE to hydrolysis by artificial gastric acid was conducted according to Wichienchot et al. (2010) method. The artificial gastric acid used was hydrochloric acid buffer (composition in $\mathrm{g} / \mathrm{l}$ : NaCL, 8; $\mathrm{KCl}, 0.2$; $\left.\mathrm{Na}_{2} \mathrm{HPO}_{4} .2 \mathrm{H}_{2} \mathrm{O}, 8.25 ; \mathrm{NaH}_{2} \mathrm{PO}_{4}, 14.35 ; \mathrm{CaCl}_{2} .2 \mathrm{H}_{2} \mathrm{O}, 0.01 ; \mathrm{MgCl}_{2} .6 \mathrm{H}_{2} \mathrm{O}, 0.18\right)$.
BFOE samples were dissolved in distilled water. The concentration of BFOE used to testing of the hydrolysis resistance by artificial gastric acid were the three concentrations that yielded the highest values in the probiotic growth stimulation test, each repeated triplicate . Commercial fructooligosaccharide (FOS) was used as a reference at the same concentration as BFOE. The $\mathrm{pH}$ of HCL buffer was adjusted to 2.5 using $5 \mathrm{M}$ HCL then mixed with BFOE at each concentration in a ratio of $1: 1(\mathrm{v} / \mathrm{v})$. The reaction mixture was incubated in water bath for $3 \mathrm{~h}$ at 37 ${ }^{\circ} \mathrm{C}$. The total carbohydrate was determined by phenol-sulfuric acid method before incubation. Reduction of sugar content was carried out for $0,1,2$, and $3 \mathrm{~h}$ by DNS method. Each concentration was repeated triplicate. The percent hydrolysis of the samples was calculated using this formula (Wichienchot et al., 2010): hydrolysis $(\%)=($ reducing sugar at final $\mathrm{h}-$ reducing sugar at initial h) $\times 100 /$ (total sugar content - initial reducing sugar content).

Resistance of Buton Forest Onion Extract (BFOE) to hydrolysis by $\alpha$ amylase

Two units/mL of $\alpha$-amylase (Novozymes, Denmark) was dissolved in a buffer of $20 \mathrm{mM}$ sodium phosphate at $\mathrm{pH}$ 8.5. The concentration of BFOE used to testing of the hydrolysis resistance by $\alpha$-amylase were the three concentrations which yielded the highest values in the probiotic growth stimulation test. The three concentration of BFOE was mixed with $\alpha$-amylase at a ratio of $1: 1(\mathrm{v} / \mathrm{v})$ then incubated in water bath at $37{ }^{\circ} \mathrm{C}$ for $3 \mathrm{~h}$. The total carbohydrate was determined by phenol-sulfurc acid method and reducing sugar content was determined by DNS method.

\section{Buton Forest Onion Extract (BFOE) as an Antioxidant}

An analysis of DPPH free-radical scavenger (2,2-diphenyl-1-picrylhydrazyl) was conducted according to the method of Mayur et al. (2010). The concentrations of BFOE used to analysis of DPPH free-radical scavenger were the three concentrations which yielded the highest values in the probiotic growth stimulation test, each repeated triplicate. The BFOE was dissolved with ethanol. Two $\mathrm{mL}$ of BFOE was mixed with $1 \mathrm{~mL}$ of $0.5 \mathrm{mM} \mathrm{DPPH}$ then shaken and left for 25 minutes at $27-29{ }^{\circ} \mathrm{C}$ in a dark room. The control used $1 \mathrm{~mL}$ of $0.5 \mathrm{mM}$ DPPH solution added with $2 \mathrm{~mL}$ of ethanol and ascorbic acid as a comparison Absorbance was measured at a wavelength of $518 \mathrm{~nm}$ using a spectrophotometer. The percentage of inhibition was calculated using the formula: $\%$ inhibition $=1$. [(absorbance control - absorbance of sample) / (absorbance control)] x 100. In addition, an IC50 analysis was carried out to determine the concentration of BFOE which has the ability to inhibit DPPH free-radical scavenger by $50 \%$.

\section{Data Analysis}

The data were analyzed using one-way analysis of variance (ANOVA) then followed up with Duncan's test using the SPSS (Statistical Program Software System) and expressed as mean \pm standard deviation (SD). A significant difference were obtained if $\mathrm{P}<0.05$

\section{RESULTS AND DISCUSSION}

\section{Oligosaccharide Content of Buton Forest Onion Extract (BFOE)}

The results of the analysis of oligosaccharide content of forest onion extract using high performance liquid chromatography (HPLC) in the present study for inulins, fructooligosaccharides (FOS), galactooligosaccharides (GOS) and raffinoses were at $2.1 \%, 10 \%, 1 \%$ and $7.5 \%$, respectively. According to Ritsema \& Smeekensy (2003), various type of onion plant are able to produce prebiotic oligosaccharides. Prebiotics are foods that can be selectively utilized by beneficial intestinal microbiotas (Mohanti et al., 2018), generally short-chain and indigestible by enzymes of the host (Sekhon et al., 2010). The compound of oligosaccharides with the highest percentage found in BFOE in the study was fructooligosaccharide (FOS) than other oligosaccharides. Thus, the use of oligosaccharides from BFOE can be used as prebiotics which are expected to stimulate the host immune response. According to Saad et al. (2013), the function of fructooligosaccharides were modulate the body's immunity in the intestine in association with lymphoid tissue, increase the production of antiinflammatory cytokines, increase the natural activity of killer cells, and produce antibodies.

\section{Activity of Buton Forest Onion Extract (BFOE) in Probiotic Growth Stimulation}

All concentrations of BFOE was capable to stimulate growth of $P$. piscicida $1 \mathrm{Ub}$ (Figure 1a) and Bacillus sp. NP5 (Figure 1b). After $24 \mathrm{~h}$ of incubation, all the concentrations of BFOE was decrease in cell density of the probiotic. The concentration of $1.25 \mathrm{mg} / \mathrm{mL}$ was capable to yield the highest prebiotic activity scores after $24 \mathrm{~h}$ of incubation in both of the probiotics, $(0.17 \pm 0.02$ and $0.21 \pm$ $0.00)$. The concentration of $0.156 \mathrm{mg} / \mathrm{mL}$ was value lowest prebiotic activity score after $14 \mathrm{~h}$ of incubation in $P$. piscicida $1 \mathrm{Ub}$, which was not significantly 
different $(\mathrm{P}>0.05)$ at the concentration of $0.313 \mathrm{mg} / \mathrm{mL}$ but significantly different $(\mathrm{P}<0.05)$ from all other concentrations. The prebiotic activity scores of P. piscicida $1 \mathrm{Ub}$ at the concentrations of 1.25 and $2.5 \mathrm{mg} / \mathrm{mL}$ for $18 \mathrm{~h}$ were significantly $(\mathrm{P}<0.05)$ higher than those at other concentrations. The concentrations of $2.5,5$, and $10 \mathrm{mg} / \mathrm{mL}$ yielded prebiotic activity scores that were significantly $(\mathrm{P}<0.05)$ lower than the concentration of 0.625 and $1.25 \mathrm{mg} / \mathrm{mL}$ after $24 \mathrm{~h}$ of incubation. The stimulation of BFOE against Bacillus sp. NP5 showed that the concentration of 2.5 and $5 \mathrm{mg} / \mathrm{mL}$ yielded prebiotic activity scores significantly $(\mathrm{P}<0.05)$ higher than the other concentrations after $14 \mathrm{~h}$ of incubation but significantly $(\mathrm{P}<0.05)$ lower compared than the concentration 1.25 $\mathrm{mg} / \mathrm{mL}$ after $24 \mathrm{~h}$ of incubation.
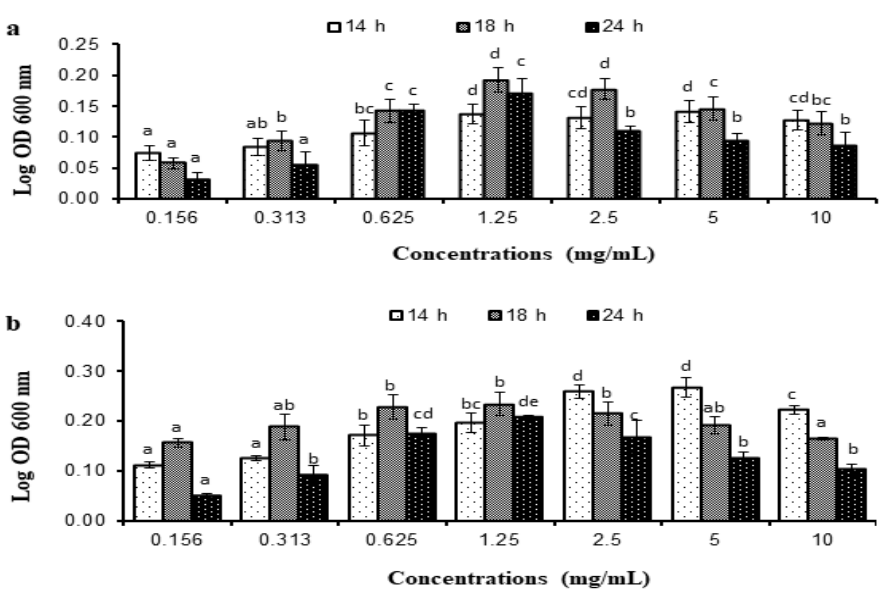

Figure 1 The scores of the activity of Buton forest onion extract (BFOE) in the growth stimulation on (a) P. piscicida 1Ub and (b) Bacillus sp. NP5. Data (mean $\pm \mathrm{SD})$ with different letters at the same $\mathrm{h}$ indicating significant different $(\mathrm{P}<$ $0.05)$.

The use of different concentrations of BFOE showed differently in the probiotic growth stimulation. The higher of the BFOE concentration $(2.5,5$, and 10 $\mathrm{mg} / \mathrm{mL}$ ) and the increase of incubation time was the lower the both prebiotic activity. It is assumed that the role of the phytochemical compounds in BFOE as antibacterial agents is greater than that of prebiotics. The growth of $P$. piscicida $1 \mathrm{Ub}$ and Bacillus sp. NP5 at the concentrations of 5 and $10 \mathrm{mg} / \mathrm{mL}$ decreased after $24 \mathrm{~h}$ of incubation. The concentration of $1.25 \mathrm{mg} / \mathrm{mL}$ was the optimal concentration of BFOE for stimulating the growth of $P$. piscicida $1 \mathrm{Ub}$ and Bacillus sp. NP5 for $14 \mathrm{~h}$ to $24 \mathrm{~h}$ of incubation. Sawangwang et al. (2018) showed that the prebiotic oligosaccharides mushroom extracts are capable to stimulate the growth of Lactobacillus acidophilus and Lactobacillus plantarum for $24 \mathrm{~h}$ of incubation. Another study by Azmi et al. (2012) which used extracts of the Gigantochloa levis shoots, show the activity of prebiotics which could act as a carbon source so as to stimulate the growth of probiotic. The ability of oligosaccharides from BFOE to stimulate the growth of probiotics in this study is expected to improve host health. The fructooligosaccharides have function to improve the intestinal health by stimulating intestinal probiotics and increase short-chain fatty acids (SCFAs) such as acetate, propionate, and butyrate (Saad et al. 2013). The use of BFOE has been capability to increase the microbiota diversity in the intestinal of white shrimp Litopenaeus vannamei, digestibility, growth, immune response and resistance to the pathogenic parahaemolyticus (data under review).

\section{Resistance of Buton Forest Onion Extract (BFOE) to artificial gastric acid}

The highest percentage of gastric acid hydrolysis of the oligosaccharide of BFOE at concentrations of $0.625,1.25$, and $2.5 \mathrm{mg} / \mathrm{mL}$ after $3 \mathrm{~h}$ of incubation were 2.53 $\pm 0.80 \%, 4.72 \pm 0.36 \%$, and $8.25 \pm 0.25 \%$, respectively (Figure 2). The percentage of hydrolysis of reference prebiotic (FOS) was higher than the BFOE at the same concentration for $3 \mathrm{~h}$ of incubation. The BFOE was more resistant compared to the reference prebiotic (FOS). The hydrolysis percentage of artificial gastric acid of commercial FOS increased after $3 \mathrm{~h}$ of incubation. The degrees of hydrolysis at the concentrations of $0.625,1.25$, and $2.5 \mathrm{mg} / \mathrm{mL}$ were $7.09 \pm$ $0.54 \%, 19.83 \pm 2.26 \%$, and $28.73 \pm 0.83 \%$, respectively.

In addition to being able to stimulate the growth of probiotics, the oligosaccharides in BFOE are also resistant to artificial gastric acid and $\alpha-$ amylase. This was also found in previous study by Azmi et al. (2012), which showed that the prebiotic extract of G. levis shoots, not only is able to stimulate the growth of probiotics, but also is resistant to artificial gastric acid at up to $99 \%$. The percentage of oligosaccharide hydrolysis in this study became higher with the increase in the concentration of BFOE. The largest percentage of hydrolysis in $2 \mathrm{~h}$ of incubation was found at the concentration yielded $2.5 \mathrm{mg} / \mathrm{mL}$ (7.94\%). Meanwhile, the concentrations of 0.625 and $1.25 \mathrm{mg} / \mathrm{mL}$ yielded $4.45 \%$ and $2.33 \%$, respectively. Thus, when the oligosaccharides from BFOE are in the stomach for $2 \mathrm{~h}$, an estimated $92 \%$ of them will reach the intestine. Another study shows that the percentage of gastric acid hydrolysis in dragon fruit after $2 \mathrm{~h}$ of incubation at $\mathrm{pH} 2$ was $2.43 \%$, while that of the reference (inulin) was $23.22 \%$ (Wichienchot et al., 2010). The gluco-oligosaccharides produced by Gluconobacter oxydans NCIMB 4943 are capable of being resistant to $98.4 \%$ of human gastric acid conditions (Wichienchot et al., 2006).

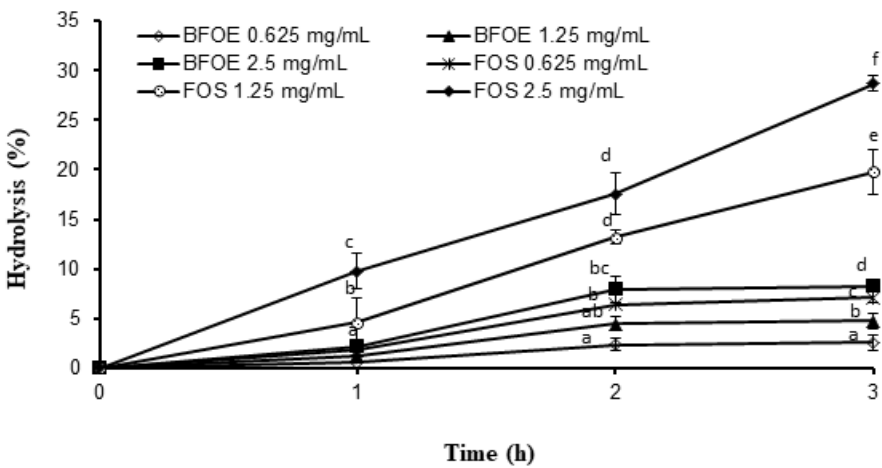

Figure 2 The resistance of Buton forest onion extract (BFOE) and fructooligosaccharides (FOS) to artificial gastric acid at different concentrations. Data (mean $\pm \mathrm{SD}$ ) with different letters at the same $\mathrm{h}$ indicate significant difference $(\mathrm{P}<0.05)$.

\section{Resistance of Buton Forest Onion Extract (BFOE) to $\alpha$-amylase}

The highest percentages of hydrolysis by $\alpha$-amylase of the oligosaccharide in BFOE at the concentrations of $0.625,1.25$, and $2.5 \mathrm{mg} / \mathrm{mL}$ after $3 \mathrm{~h}$ of incubation were $17.58 \pm 1.46 \%, 23.48 \pm 2.13 \%$ and $27.52 \pm 1.68$, respectively (Figure 3) The percentage of $\alpha$-amylase hydrolysis of BFOE at $2.5 \mathrm{mg} / \mathrm{mL}$ was significantly higher $(\mathrm{P}<0.05)$ than those at other concentrations during the incubation period, with that at $1.25 \mathrm{mg} / \mathrm{mL}$ being the second highest. The lowest percentage of hydrolysis by $\alpha$-amylase was at the concentration of $0.625 \mathrm{mg} / \mathrm{mL}$. The percentages of hydrolysis of reference prebiotic from commercial fructooligosaccharides (FOS) at the concentrations of $0.625,1.25$, and 2.5 $\mathrm{mg} / \mathrm{mL}$ after $3 \mathrm{~h}$ of incubation were $23.11 \pm 2.48 \%, 40.73 \pm 1.60 \%$, and $50.34 \pm$ $5.05 \%$, respectively. The percentage of $\alpha$-amylase hydrolysis in this study was lower than that in the study by Wichienchot et al. (2010), which used dragon fruit (32\%). Prebiotics can be tolerant of stomach acid and $\alpha$-amylase in the digestive tract and can be utilized by beneficial microbes (Chowdhury et al., 2015).

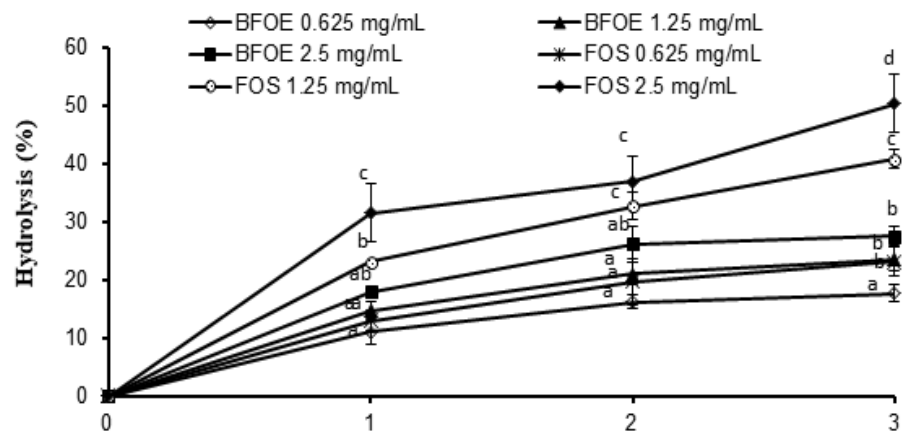

Time (h)

Figure 3 The resistance of Buton forest onion extract (BFOE) and fructooligosaccharides (FOS) to $\alpha$-amylase at different concentrations. Data (mean $\pm \mathrm{SD})$ with different letters at the same $\mathrm{h}$ indicate significant difference $(\mathrm{P}$ $<0.05)$.

\section{Buton Forest Onion Extract (BFOE) as an Antioxidant}

The ability of BFOE at different concentrations as compared with ascorbic acid can be seen in Table 1. The ability of an extract concentration to inhibit or reduce DPPH free radical activity by $90.09 \pm 1.3 \%-99.39 \pm 0.35 \%$, than the ability of ascorbic acid by $81.02 \pm 0.28 \%-86.71 \pm 0.08 \%$. The percentage of inhibition of BFOE at $2.5 \mathrm{mg} / \mathrm{mL}$ was significantly higher $(\mathrm{P}<0.05)$ than the other concentrations. Furthermore, test results of antioxidant activity in IC50 are expressed in $\mu \mathrm{g} / \mathrm{mL}$. The IC50 value in the BFOE in this study $(1.48 \pm 0.35$ $\mu \mathrm{g} / \mathrm{mL})$ was higher than that in ascorbic acid $(0.32 \pm 0.23 \mu \mathrm{g} / \mathrm{mL})$. This indicates that the ability of BFOE was lower than that of ascorbic acid. However, the IC50 value of BFOE was very strong. As explained by Molyneux (2004), the antioxidant activity of a compound can be categorized as very strong if the IC50 value is $<50 \mu \mathrm{g} / \mathrm{mL}$. The high antioxidant ability in this study assumed to be the effect of the phytochemical compounds contained in BFOE such as xanthones, isoquinolines, naphtalenes, and phenolics groups. The compound of xanthones was highest than the other compunds (Munaeni et al. 2019a). Mahaburasakam et al. (2009) and Ieyama et al. (2011) explain that the phytochemical compounds 
in the naphtalenes, naphtoquinones, anthraquinones group are antioxidant compounds that have the ability to inhibit free radical activity. Xanthones and phenolics compounds are capable to inhibit the growth of cancer cells (Zhang $\boldsymbol{e}$ al., 2018; Yang et al., 2019). Phenolic compounds are capable of donating hydrogen atoms to free radicals to form more radicals derived from phenols (Jongberg et al., 2013).

Table 1 The DPPH free-radical scavenging activity of Buton Forest Onion Extract (BFOE) and ascorbic acid at different concentrations

\begin{tabular}{lll}
\hline \multirow{2}{*}{ Concentrations $(\mathbf{m g} / \mathbf{m L})$} & \% inhibition & \\
\cline { 2 - 3 } & BFOE & Ascorbic acid \\
\hline 0.625 & $90.09 \pm 1.31 \mathrm{a}$ & $81.02 \pm 0.28 \mathrm{a}$ \\
1.25 & $96.31 \pm 1.48 \mathrm{~b}$ & $84.17 \pm 0.33 \mathrm{~b}$ \\
2.5 & $99.39 \pm 0.35 \mathrm{c}$ & $86.71 \pm 0.08 \mathrm{c}$ \\
\hline $\mathrm{IC} 50(\mu \mathrm{g} / \mathrm{mL})$ & $1.48 \pm 0.35$ & $0.32 \pm 0.23$ \\
\hline
\end{tabular}

Data (mean \pm SD) $(n=3)$ with different letters at the same column indicate significant difference $(\mathrm{P}<0.05)$.

\section{CONCLUSION}

The content of the oligosaccharides of Buton forest onion extract (BFOE) was included inulins, fructooligosaccharides (FOS), galactooligosaccharides (GOS) and raffinoses. The oligosaccharides of BFOE were found capable to stimulate the growth of $P$. piscicida $1 \mathrm{Ub}$ and Bacillus sp. NP5. The optimum BFOE concentration to stimulate the growth of probiotics. The Buton forest onion extract (BFOE) was resistant to artificial gastric acid and $\alpha$-amylase. The BFOE was capable to DPPH radical scavenge with IC50 of $1.48 \mu \mathrm{g} / \mathrm{mL}$. The BFOE in this study has the potential to be a prebiotic and an antioxidant.

Acknowledgments: This article is part of the dissertation by Waode Munaeni in the Department of Aquaculture, Faculty of Fishery and Marine Science, Bogor Agricultural University. The research is financially supported by the Ministry of Research, Technology, and Higher Education and the Lembaga Pengelola Dana Pendidikan (LPDP, Indonesia Endowment Fund for Education) for funding the present study in the form of the BUDI-DN (Beasiswa Unggulan Dosen Indonesia- Dalam Negeri, The Indonesian Superior Lecturer ScholarshipDomestic) scholarship.

\section{REFERENCES}

AOAC (Association of Analytical Communities) Method 997.08. Fructans in Food Products.

AOAC (Association of Analytical Communities) Method 2002.02. Determination of Trans-Galactooligosaccharides in Foods by AOAC Method 2001.02. https://tools.thermofisher.com/content/sfs/brochures/AN-155-IC-Trans Galactooligosaccharides-Foods-LPN1547-EN.pdf.

AZMI, A. F. M. N., MUSTAFA, S., HASIM, A. M. D., \& MANAP, Y. A (2012). Prebiotic Activity of Polysaccharides Extracted from Gigantochloa Levis (Buluh beting) Shoots. Molecules, 17, 1635-1651. https://doi:10.3390/molecules17021635.

CARABIN, I. G., \& FLAMM, W. G. (1999). Evaluation of safety on inulin and oligofructose as dietary fiber. Regul. Toxicol. Pharmacol, 30, 268-282. https://doi:10.1006/rtph.1999.1349.

FEBRINDA, A. E. (2014). Antioxidants and Antidiabetic Potency of Aqueous and Ethanolic Extracts of Bawang Dayak Bulbs (Eleutherine palmifolia) in vitro and in vivo. [Thesis]. Bogor (ID): Institut Pertanian Bogor.

FEBRINDA, A. E., YULIANA, N. D., RIDWAN, E., WRESDIYATI, T., \& ASTAWAN, M. (2014). Hyperglycemic control and diabetes complication preventive activities of Bawang Dayak (Eleutherine palmifolia L. Merr.) bulbs extracts in alloxan-diabetic rats. International Food Research Journal, 21(4), $1405-1411$

GIBSON, G. R., PROBERT, H. M., RASTALL, R. A., \& ROBERFROID, M. B (2004). Dietary modulation of the human colonic microbiota: updating the concept of prebiotics. Nutrition Research Reviews, 17, 259-275 https://doi:10.1079/NRR200479.

HALLIWELL, B. (1990). How to characterize a biological antioxidant. Free Radical Research Communications, 9(1), 1-32. https://doi:10.3109/10715769009148569.

HUEBNER, J., WEHLING, R. L., PARKHURST, A., \& HUTKINS, R. W (2008). Effect of processing conditions on the prebiotic activity of commercial prebiotics. International Dairy Journal, 18, 287-293. https://doi:10.1016/j.idairyj.2007.08.013.

IFESAN, B. O. T., HAMTASIN, C., MAHABUSARAKAM, C., \& VORAVUTHIKUNCHAI, S. P. (2009). Inhibitory effect of Eleutherine americana Merr. extract on Staphylococcus aureus isolated from food. Journal of Food Scienc, 7(1), 31-36. https://doi:10.1111/j.1750-3841.2008.01004.x.

INSANU, M., KUSMARDIYANI, S., \& HARTATI, R. (2014). Recent studies on phytochemicals and pharmacological effects of Eleutherine americana Merr Procedia Chemistry, 13, 221-228. https://doi:10.1016/j.proche.2014.12.032
IEYAMA, T., GUNAWAN-PUTERI, M. D. P. T, \& KAWABATA, J. (2011). $\alpha$ Glucosidase inhibitors from the bulb of Eleutherine americana. Food Chemistry, 128, 308-311. https://doi:10.1016/j.foodchem.2011.03.021

JONGBERG, S., TORNGREN, M. A., GUNVIG, A., SKIBSTED, L. H., \& LUND, M. N. (2013). Effect of green tea or rosemary extract on protein oxidation in Bologna type sausages prepared from oxidatively stressed pork Meat Sci, 93, 538-546. https://doi:10.1016/j.meatsci.2012.11.005.

KIM, H. S., QUON, M. J., \& KIM, J. A. (2014). New insights into the mechanisms of polyphenols beyond antioxidant properties; lessons from the green tea polyphenol, epigallocatechin 3-gallate. Redox Biology, 2, 187-95. https://doi:10.1016/j.redox.2013.12.022.

MAHABUSARAKAM, W., HEMTASIN, C., CHAKTHONG, S. VORAVUTHIKUNCHAI, S. P., \& OLAWUMI, I. B. (2010). Naphthoquinones, Anthraquinones and Naphthalene Derivatives from the Bulbs of Eleutherine americana. Planta Med, 76, 345-349. https://doi:10.1055/s-0029-1186143.

MAHIOUS, A. S., GETESOUPE, F. J., HERVI, M., METAILLER, R., \& OLLEVIER, F. (2006). Effect of dietary inulin and oligosaccharides as prebiotics for weaning turbot, Psetta maxima (Linnaeus, C.1758). Aquaculture Internasional, 14(3), 219-229. http://dx.doi.org/10.1007/s10499-005-9003-4.

MAYUR, B., SANDESH, S., SHRUTI, S., \& SUNG-YUM, S. (2010). Antioxidant and $\alpha$-glucosidase inhibitory properties of Carpesium abrotanoides L. J Med Plants Res, 4, 1547-1553. http://dx.doi.org/10.5897/JMPR10.210.

MIHAYLOVA, D., VRANCHEVA, R., IVANOV, I., \& POPOVA, A. (2019). Phytochemical Profile and Antioxidant Activity of Water Pepper (Polygonum hydropiper L.). Journal of Microbiology, Biotechnology and Food Science, (5), 1205-1208. http://dx.doi:10.15414/jmbfs.2019.8.5.1205-1208.

MOHANTI, D., MISRA, S., MOHAPATRA, S., \& SAHU, P. S. (2018) Prebiotics and synbiotics: Recent concepts in nutrition. Food Bioscience, https://doi.org/10.1016/j.fbio.2018.10.008

MOLYNEUX, P. (2004). The use of stable free radical diphenylpicrylhydrazyl (DPPH) for estimating antioxidant activities. Songklanakarin Journal Science Technology, 26(2), 211-219.

MUNAENI, W., PARIAKAN, A., YUHANA, M., SETIAWATI, M., \& ABIDIN, L. O. B. (2017). In Vitro Phytochemical and Inhibitory Potential Tests of Buton Forest Onion Extract (Eleutherine palmifolia L. Merr.) on Vibrio harveyi. Microbiology Indonesia, 11(3), 75-80. doi.org/10.5454/mi.11.3.1.

MUNAENI, W., WIDANANRI, W., YUHANA, M., SETIAWATI, M., \& WAHYUDI, A. T. (2019). Phytochemical analysis and antibacterial activities of Eleutherine bulbosa (Mill.) Urb. extract against Vibrio parahaemolyticus. Asian Pacific Journal of Tropical Biomedicin, 9(9): 397-404. doi: 10.4103/2221 1691.267669

MUNAENI, W., DISNAWATI , YUHANA, M., SETIAWATI, M., ABIDIN, L. O. B., \& KURNIAJI A. (2017).Buton Forest Onion Extract (Eleutherine bulbosa (Mill.) Potential on Growth Performance of Vannamei Shrimp (Litopenaeus vannamei). Pakistan Journal of Biological Sciences, 22(1), 15-20. DOI: 10.3923/pjbs.2019.15.20.

PHOEM, A. N., \& VORAVUTHIKUNCHAI, S. P. (2013). Eleutherine americana as a growth promotor for infant intestinal microbiota. Anaerobe, 20, 14-19.

PUTRA, A. N., UTOMO, N. B. P., \& WIDANARNI. (2015). Growth Performance of Tilapia (Oreochromis niloticus) Fed with Probiotic, Prebiotic and Synbiotic in Diet. Pakistan Journal of Nutrition, 14, 263-268. https://doi.org/10.3923/pjn.2015.263.268.

RITSEMA, T., \& SMEEKENS, S. (2003). Fructans: Beneficial for plants and humans. Current Opinion in Plant Biology, 6, 223-230. https://doi.org/10.1016/S1369-5266(03)00034-7.

SAHREEN, S., KHAN, M. R., \& KHAN, R. A. (2010). Evaluation of antioxidant activities of various solvent extracts of Carissa opacus fruits. Food Chem, 122, 1205-1211. https://doi.org/10.1016/j.foodchem.2010.03.120.

SAWANGWAN, T., WANSANIT, W., PATTANI, L., \& NOYSANG, C. (2018). Study of prebiotic properties from edible mushroom extraction. $\begin{array}{llll}\text { Agriculture } \quad \text { and } & \text { Natural } & \text { 5esources, } & \text { 52, }\end{array}$ https://doi.org/10.1016/j.anres.2018.11.020.

SEKHON, B. S., \& JAIRATH, S. (2010). Prebiotics, probiotics and synbiotics: An overview. Indian Journal of Pharmaceutical Education and Research, 1, 13 36.

SUBRAMANIAM, K., SURIYAMOORTHY, S., WAHAB, F., SHARON, F.B. \& REX, G. R. Antagonistic activity of Eleutherine bulbosa (Mill.) Urb. Linn. Asian Pacific Journal of Tropical Disease, S491-S493.

WICHIENCHOT, S., PRASERTSAN, P., HONGPATTARAKERE, T., GIBSON, G. R., \& RASTALL, R. A. (2006). In vitro fermentation of mixed linkage gluco-oligosaccharides produced by Gluconobacter oxydans NCIMB 4943 by the human colonic microflora. Current Issues in Intestinal Microbiology, 7, 7-12.

WICHIENCHOT, S., JATUPORNPIPAT, M., \& RASTALL, R. A. (2010) Oligosaccharides of pitaya (dragon fruit) flesh and their prebiotic properties Food Chemistry, 120, 850-857. https://doi:10.1016/j.foodchem.2009.11.026.

WIDANARNI, TEPU, I., SUKENDA, \& SETIAWATI, M. (2009). Selection of probiotic bacteria for biocontrol of vibriosis on tiger shrimp (Penaues monodon) larvae using co-culture method. Jurnal Riset Akuakultur, 4(1), 95-105. 
YANG, H. X., LI, W., LI, Q., AI, H.L., LI, Z. H., HUANG, R., FENG, T., LIU, J. K. (2019). Piperidine alkaloids and xanthone from the roots of Caulophyllum
robustum
Maxim.
Fitoterapia,
132 ,
$22-25$.

https://doi.org/10.1016/j.fitote.2018.07.014.

ZHANG, B. J., FU, W. W., WU, R., YANG, J. L., YAO, C. Y., YAN, B. X

TAN, H. S., ZHENG, C.W., SONG, Z. J., XU, H. X. (2018). Bioactive scalemic

caged xanthones from the leaves of Garcinia bracteata. Bioorganic Chemistry, doi: https://doi.org/10.1016/j.bioorg.2018.10.041. 